\title{
Relationship between endotoxaemia and protein concentration of ascites in cirrhotic patients
}

\author{
K. TARAO ${ }^{1}$, T. MOROI, Y. NAGAKURA, T. IKEUCHI, T. SUYAMA, \\ O. ENDO, AND K. FUKUSHIMA \\ From the First Department of Medicine, Yokohama City University School of Medicine, Yokohama, \\ Japan
}

SUMMARY Endotoxaemia was investigated by the Limulus assay in 42 cirrhotic patients with ascites and in 33 without ascites. The incidence of endotoxaemia in the former group (59.5\%) was significantly $(\mathrm{P}<0.05)$ higher than in the latter $(36.4 \%)$. Correlation between endotoxaemia and specific gravity and concentrations of total protein, albumin, and globulin in ascitic fluid was studied in the group with ascites. The specific gravity of ascites in 25 patients with endotoxaemia was significantly greater than that in 17 patients without endotoxaemia $(P<0.01)$. The concentration of total protein in patients with endotoxaemia $(13.95 \pm 7 \cdot 18 \mathrm{~g} / \mathrm{l}$, mean $\pm \mathrm{SD}$ ) was nearly twice as high $(\mathrm{P}<0.01)$ as in patients without endotoxaemia $(7.49 \pm 3.60 \mathrm{~g} / \mathrm{l})$. The protein content of those who showed reactions greater or equal to $2(+)$ in the Limulus assay $(16 \cdot 78 \pm 7 \cdot 14 \mathrm{~g} / \mathrm{l})$ was significantly $(\mathrm{P}<0.05)$ higher than in those with $1(+)$ reaction $(11.26 \pm 6.33 \mathrm{~g} / \mathrm{l})$. Moreover, the concentration of albumin in patients with endotoxaemia $(7.68 \pm 4.60 \mathrm{~g} / \mathrm{l})$ was more than twice that of the patients without endotoxaemia $(3.39 \pm 1.58 \mathrm{~g} / 1, \mathrm{P}<0.01)$. On the other hand, globulin concentration in patients with endotoxaemia was 1.6 times that of patients without endotoxaemia $(\mathrm{P}<0.01)$. Similar differences were noted between endotoxaemic and non-endotoxaemic patients in the ascites-to-serum ratio in protein, albumin, and globulin. These results suggest that in liver cirrhosis endotoxaemia may cause an increase in protein concentrations in ascitic fluid, and that it may be a precipitating factor in the formation of ascites.

Among the various biological actions of endotoxin, an accelerating effect on capillary permeability to macromolecules was first demonstrated by Chien et al. (1963) in experimental animals. Endotoxin was also shown experimentally to cause portal hypertension by constriction of hepatic venules (MacLean et al., 1956; Weil et al., 1956; Chien et al., 1964). Moreover, with regard to hepatic venous outflow block, it is known clinically that ascitic fluid resulting from hepatic venous obstruction such as is found in the Budd-Chiari syndrome is characterised by a high protein content (Gibson, 1960). It is also well established that endotoxaemia is encountered frequently in cirrhotic patients with ascites (Liehr et al., 1975; Clemente et al., 1977; Tarao et al., 1977). If the above mentioned effects of endotoxin are present in cirrhotic patients with

\footnotetext{
'Present address: Dr Kazuo Tarao, Northwestern Apartments, Apartment 728, 1725 Orrington Avenue, Evanston, Illinois 60201, USA.
}

Received for publication 9 October 1978 ascites, the ascitic fluid of patients with endotoxaemia should contain more protein than in those without endotoxaemia. The present study was designed to investigate the relationship between endotoxaemia and the specific gravity-protein content as well as content of albumin-of the ascitic fluid of cirrhotic patients.

\section{Methods}

Subjects investigated comprised 75 cirrhotic patients, 42 (36 males, six females) with ascites and 33 (23 males, 10 females), without ascites. They were inpatients at the Yokohama City University Hospital between 8 September 1976 and 3 March 1978. Diagnosis was made by biopsy histology characterised by complete bridging of the portal areas with fibrous bands and disorganisation of the lobules. Their ages ranged from 37 to 68 years with a mean of 51 years in the former group and from 35 to 70 years with a mean of 53 years in the latter group. The cirrhotic group with ascites comprised alcoholic 205 
cirrhosis (20 patients), post-hepatitic cirrhosis (eight), cryptogenic cirrhosis (13), and primary biliary cirrhosis (one). The cirrhotic group without ascites consisted of alcoholic cirrhosis (17), post-hepatitic cirrhosis (five) and cryptogenic cirrhosis (11). HBsAg was detectable in the serum of 10 patients in the former and six in the latter group by radioimmunoassay. At the time of investigation, 21 of 42 in the former group and seven of 33 in the latter group were on diuretics. As to the other medications, no other drugs which would influence the study were administered.

Liver function study included: total protein (estimated by the method of Gornall et al. (1949), normal 68 to $80 \mathrm{~g} / \mathrm{l}$ ), serum alkaline phosphatase (INU), serum glutamic oxalacetic transaminase (INU), thymol turbidity test (TTT, Japanese standard method, 0 to $5.5 \mathrm{Kunel} U$ ), total and prompt-reacting bilirubin (estimated by the modified method of Michaëlsson et al. (1965), total bilirubin 5 to $17 \mu \mathrm{mol} / \mathrm{l}$ ), and bromsulphthalein retention (BSP, less than $5 \%$ in 45 minutes). Alphafetoprotein was determined in all patients by radioimmunoassay and those whose condition was complicated by hepatoma were excluded. Total protein in the ascitic fluid was determined by the biuret method. Disc electrophoresis (Ornstein, 1964) was used for electrophoretic analysis of ascites.

Blood-samples were obtained under aseptic conditions with pyrogen-free syringes. Endotoxinlike activity was measured immediately after sampling by the Limulus assay as described by Levin et al. (1970). All glassware was rendred pyrogen-free by heating at $175^{\circ} \mathrm{C}$ for three hours (Yin et al., 1972). All procedures were carried out under sterile conditions. The amoebocyte lysate used in Limulus assay was provided by Difco Laboratories. Heparinised plasma was shaken vigorously with chloroform $(1: 0 \cdot 25)$ for four hours, and the emulsion produced was centrifuged at $2500 \mathrm{rpm}$ for 10 minutes; $0 \cdot 1 \mathrm{ml}$ of the middle layer was taken and mixed with $0.1 \mathrm{ml}$ of pyrogen-free distilled water containing amoebocyte lysate. The mixture was incubated at $37^{\circ} \mathrm{C}$ for 24 hours and examined after one, four, and 24 hours. The test was considered positive when a definite gelation occurred. The results were scored as follows: $(3+)$ complete gelation-that is, shape of the gel did not change even if the tube were laid in a horizontal position; $(2+)$ incomplete gelation-that is, shape of the gel changed slightly but did not flow out of the tube in the horizontal position; $(+)$ definite increase in viscosity and turbidity; and (-) slight flocculation only. This last (-) score was interpreted as a negative result. Titration of the concentration of purified $E$. coli endotoxin (Difco Laboratories) dissolved in normal plasma from the batch used in the initial tests showed: $(3+) \geqq 5 \mathrm{ng} / \mathrm{ml}, 5 \mathrm{ng} / \mathrm{ml}>$ $(2+) \geqq 1 \mathrm{ng} / \mathrm{ml}, 1 \mathrm{ng} / \mathrm{ml}>(1+) \geqq 0.5 \mathrm{ng} / \mathrm{ml}$. The result of each test was read by two independent observers. The sensitivity of the lysate preparation that was used allowed endotoxin concentrations above $0.5 \mathrm{ng} / \mathrm{ml}$ to be detected. In all patients cultures of blood and ascites were examined on the day of the endotoxin assay.

\section{COAGULATION STUDIES}

Plasma fibrinogen was estimated with a biuret method, and fibrinogen degradation products (FDP) by staphylococcal clumping test; platelets were counted by phase microscopy; prothrombin time and activated partial thromboplastin time were also measured. All of the coagulation studies were made within two days of the Limulus assay.

The statistical significance of differences was calculated by Student's $t$ test.

\section{Results}

Of the 42 plasma specimens of cirrhotic patients with ascites, $25(59.5 \%)$ showed positive (group A), and 17 showed negative (group B) results in Limulus assay. In more detail, 12 of group A showed reactions greater or equal to $2+$ (group $A_{1}$ ), while the remaining 13 showed $1+$ reactions (group $A_{2}$ ). Comparison of group $\mathbf{A}$ and group $\mathbf{B}$ revealed no significant differences in liver function tests (Table),

Table Biochemical laboratory tests *

\begin{tabular}{|c|c|c|c|c|c|c|c|c|c|c|}
\hline Patients & $\begin{array}{l}\text { No. of } \\
\text { patients }\end{array}$ & Age $(y r)$ & $\begin{array}{l}B P \\
(m m H g)\end{array}$ & $\begin{array}{c}T P \\
(g / l)\end{array}$ & $\begin{array}{l}\text { Albumin } \\
(g / l)\end{array}$ & $\begin{array}{l}A l \cdot-p h . \\
(U I / L)\end{array}$ & $\begin{array}{l}S-G O T \\
(U I / I)\end{array}$ & $T T T$ & $\begin{array}{c}\text { Total } \\
\text { bilirubin } \\
(\mu \mathrm{mol} / l)\end{array}$ & $\begin{array}{c}B S P \\
\left(45^{\prime}\right)\end{array}$ \\
\hline \multicolumn{11}{|l|}{ Cases with ascites } \\
\hline With endotoxaemia & 25 & $50.8 \pm 10.1$ & $131 \cdot 2 \pm 21 \cdot 8 / 80 \cdot 2 \pm 11 \cdot 9$ & $62 \pm 9$ & $28 \pm 6$ & $150 \pm 60$ & $153 \pm 113$ & $7 \cdot 4 \pm 5 \cdot 0$ & $39 \pm 34$ & $22.4 \pm 3.8$ \\
\hline $\begin{array}{l}\text { Without endotoxaemia } \\
\text { Cases without ascites }\end{array}$ & 17 & $51.6 \pm 8.9$ & $130 \cdot 7 \pm 16.9 / 79 \cdot 6 \pm 12 \cdot 1$ & $63 \pm 8$ & $26 \pm 4$ & $133 \pm 48$ & $141 \pm 108$ & $8 \cdot 1 \pm 6 \cdot 2$ & $236 \pm 31$ & $20.9 \pm 4.1$ \\
\hline $\begin{array}{l}\text { With endotoxaemia } \\
\text { Without endotoxaemia }\end{array}$ & $\begin{array}{l}12 \\
21\end{array}$ & $\begin{array}{l}53 \cdot 8 \pm 12 \cdot 3 \\
52 \cdot 1 \pm 9 \cdot 2\end{array}$ & $\begin{array}{l}138.8 \pm 20 \cdot 1 / 82.6 \pm 13.1 \\
140.2 \pm 17 \cdot 3 / 83.8 \pm 15.6\end{array}$ & $\begin{array}{l}66 \pm 8 \\
68 \pm 10\end{array}$ & $\begin{array}{l}34 \pm 5 \\
36 \pm 6\end{array}$ & $\begin{array}{l}142 \pm 56 \\
121 \pm 52\end{array}$ & $\begin{array}{l}148 \pm 104 \\
128 \pm 96\end{array}$ & $\begin{array}{l}7.8 \pm 4.9 \\
6.9 \pm 3.8\end{array}$ & $\begin{array}{l}37 \pm 23 \\
32 \pm 29\end{array}$ & $\begin{array}{l}20 \cdot 2 \pm 4.9 \\
18 \cdot 8 \pm 5 \cdot 3\end{array}$ \\
\hline
\end{tabular}

- Each value represents mean \pm SD. 
nor were there any significant differences in blood coagulation studies. Cultures of ascitic fluid and blood were all negative in the two groups.

Endotoxin was also demonstrated, although to a much lesser degree, in 12 of $33(36.4 \%)$ of the control cirrhotics who had had no ascites (group C) as mentioned in our previous report (Tarao et al., 1977). There was a significant difference $(P<0.05)$ between the incidence of endotoxaemia in cirrhotics with and without ascites.

The specific gravity of ascites in group A was $1.020 \pm 0.005$ (mean $\pm \mathrm{SD}$ ), which was significantly greater than that in group $B(1.015 \pm 0.003)$ $(P<0.01)$ (Fig. 1). The specific gravity in group $A_{1}(1.021 \pm 0.005)$ was greater than that in group $A_{2}(1.018 \pm 0.005)$, but this was not statistically significant. The protein concentration in group A was $13.95 \pm 7 \cdot 18 \mathrm{~g} / \mathrm{l}$, which was nearly twice as high as that in group $B(7.49 \pm 3.60 \mathrm{~g} / \mathrm{l})$ and this difference was highly significant $(P<0.01)$ (Fig. 2). Moreover, there was a significant difference $(P<$ $0.05)$ between group $A_{1}(16.87 \pm 7 \cdot 14 \mathrm{~g} / \mathrm{l})$ and group $A_{2}(11 \cdot 26 \pm 6 \cdot 33 \mathrm{~g} / \mathrm{l})$. The albumin concentrations in group $A(7.68 \pm 4.60 \mathrm{~g} / \mathrm{l})$ were more than twice as high as those in group $B(3.39 \pm 1.58$ $\mathrm{g} / \mathrm{l})(\mathrm{P}<0.01)$ (Fig. 3). The content of albumin in group $A_{1}(9.06 \pm 5.40 \mathrm{~g} / \mathrm{l})$ was higher than that in group $A_{2}(6 \cdot 17 \pm 3 \cdot 12 \mathrm{~g} / \mathrm{l})$, but this again was not significant. The globulin concentration in group $\mathbf{A}$

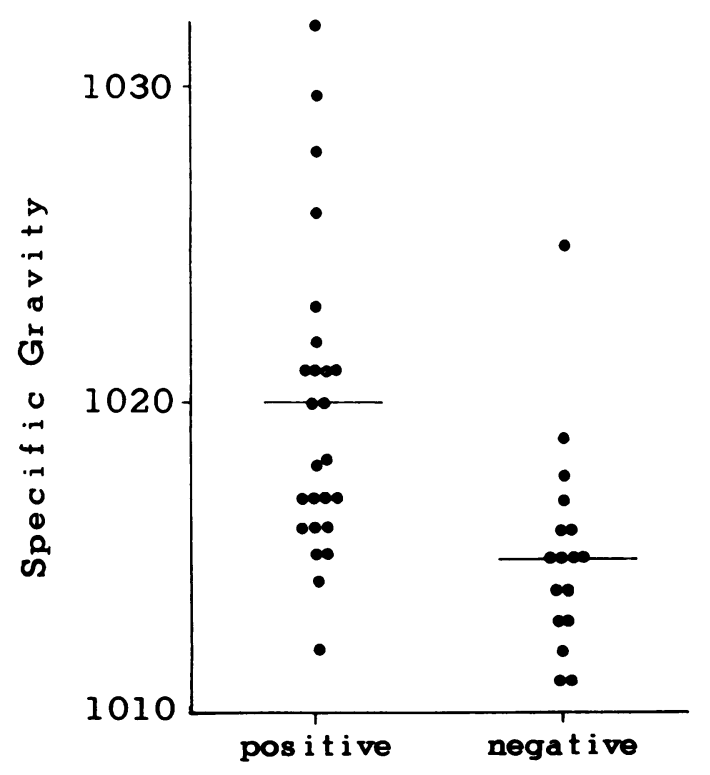

Limulus assay in plasma

Fig. 1 Correlation between specific gravity of ascitic fluid and Limulus assay in plasma.

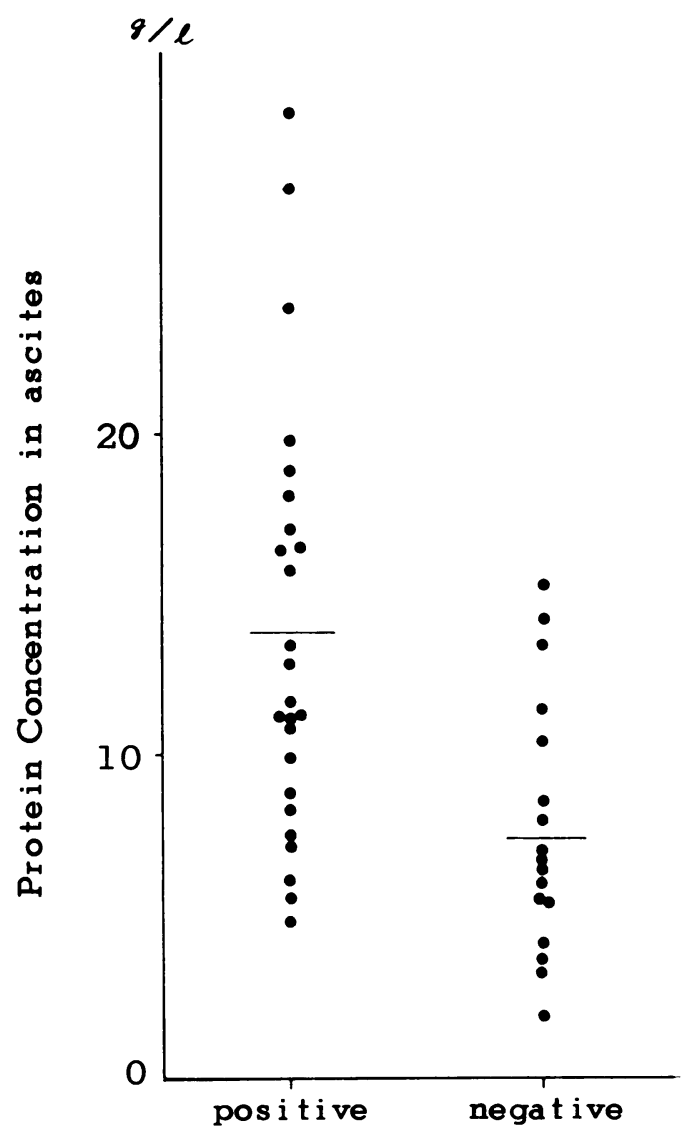

Limulus assay in plasma

Fig. 2 Correlation between protein concentration of ascitic fluid and Limulus assay in plasma.

was $6.91 \pm 3 \cdot 21 \mathrm{~g} / \mathrm{l}$, which was approximately $1 \cdot 6$ times of that in group $B(4.30 \pm 1.75 \mathrm{~g} / \mathrm{l})(\mathrm{P}<$ $0.01)$. The content of globulin in group $A_{1}(7.55 \pm$ $2.50 \mathrm{~g} / \mathrm{l})$ was higher than that in group $A_{2}(5.94 \pm$ $3.68 \mathrm{~g} / \mathrm{l})$, but this was also not significant.

The ascites-to-serum protein concentration ratio was $0.232 \pm 0.129$ in group $A$, which was significantly larger than that seen in group $B(0 \cdot 124 \pm$ $0.059)(P<0.01)$. The ratio in group $A_{1}(0.277 \pm$ $0 \cdot 129)$ was larger than that in group $A_{2}(0 \cdot 190 \pm$ $0 \cdot 118$ ), but this was not statistically significant. The ascites-to-serum albumin ratio was $0.266 \pm 0.130$ in group $A$, which was significantly larger than that in group $B(0.134 \pm 0.051)(P<0.01)$. However, there was no significant difference between group $A_{1}(0.301 \pm 0 \cdot 129)$ and group $A_{2}(0 \cdot 228 \pm 0 \cdot 127)$. Ascites-to-serum globulin ratio was $0.220 \pm 0.132$ in group A, which was significantly larger than that 


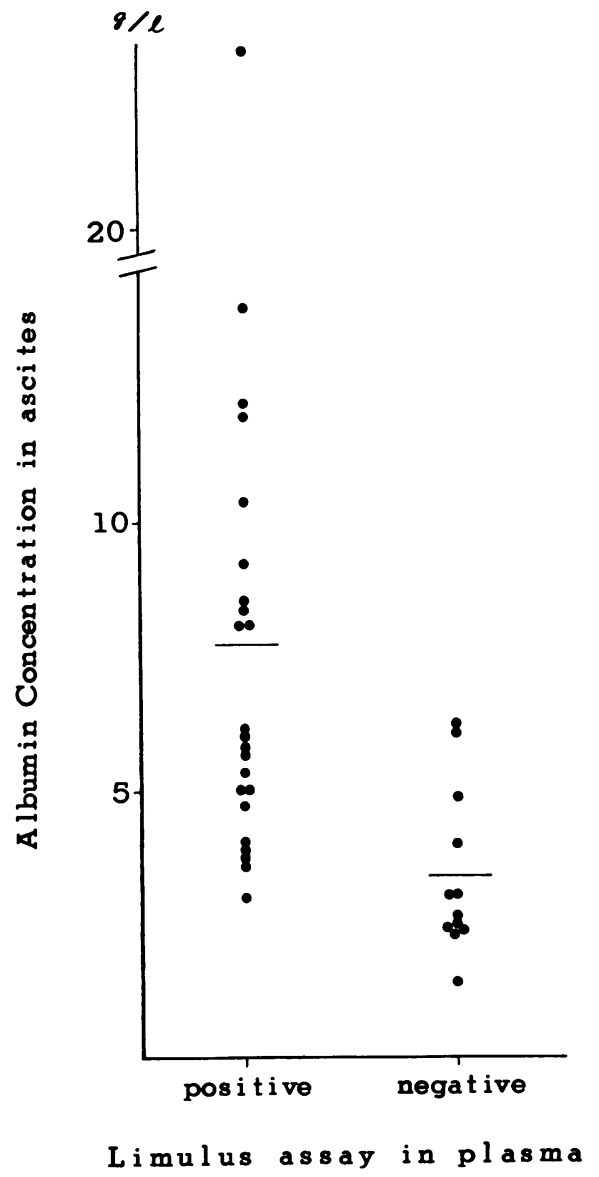

Fig. 3 Correlation between albumin concentration of ascitic fluid and Limulus assay in plasma.

in group $B(0 \cdot 109 \pm 0.045)(P<0.01)$. Nevertheless, there was no significant difference between group $\mathrm{A}_{1}(0 \cdot 258 \pm 0 \cdot 131)$ and group $\mathrm{A}_{2}(0 \cdot 179 \pm$ 0.126).

\section{Discussion}

As far as the mechanism of endotoxaemia was concerned, as there was no evidence of overt gramnegative bacterial infection in any case in our study; flora of the gastrointestinal tract appeared to be the only source of endotoxin. In normal conditions, endotoxin is absorbed from the intestinal tract (Ravin et al., 1960; Greene et al., 1961; Nolan et al., 1977), via the portal vein (Prytz et al., 1976) and completely cleared from the blood in the liver (Braude et al., 1955) by the Kupffer cells in terms of their detoxifying capacity. In support of the detoxifying capacity of the liver, Greene et al. (1961) showed that, in normal rabbits, endotoxin was found in the portal vein blood in $50 \%$ of the animals, but in only $17 \%$ of inferior vena caval bloods. If Thorotrast were given intravenously together with oral endotoxin, endotoxin was found in the blood of the inferior vena cava in $89 \%$, suggesting a reduction of the liver's capacity to extract endotoxin delivered to it from the intestine. Moreover, it is a clinically well-known fact that, in patients with a severely damaged liver, as in fulminant hepatic failure, endotoxaemia is frequently observed (Wilkinson et al., 1974). On the other hand, experimental evidence indicates that, when a venous outflow block is produced in an intestinal loop, endotoxin rapidly diffuses through the intestinal wall (Nolan and Ali, 1972). On the above bases, we had expected that endotoxaemia would frequently be found in patients with liver cirrhosis and in our patients this was indeed the case.

In the present study, a close correlation between endotoxaemia and a high protein content in the ascitic fluid was reported in patients with cirrhosis and ascites. However, the nature of the present investigation did not allow us to draw definite conclusions about whether this was a casual relationship or whether they were parallel manifestations of the cirrhotic process. Nevertheless, there seem to be several possible explanations for this phenomenon. First, endotoxin may cause an increase in capillary permeability to the macromolecules in plasma. With regard to the effect of endotoxin on capillary permeability, Chien et al. $(1963,1964)$ found in dogs that intravenous injections of Escherichia coli endotoxin resulted in increases of both flow and concentration of intravenously administered macromolecules (131 I-albumin and dextran) in the thoracic duct. They found at the same time that endogenous protein was also increased in the thoracic lymph leading to the lymph-to-serum ratios approaching unity. This same mechanism may be acting in cirrhotic patients with ascites and endotoxaemia, for ascitic fluid can exchange with blood through an enormous capillary bed under the visceral peritoneum (Prentice et al., 1952; Birkenfeld et al., 1958).

Second, it is possible that endotoxin may cause constriction of hepatic venules or small veins which results in portal hypertension of the postsinusoidal type. MacLean et al. (1956) demonstrated a marked rise in portal vein pressure in the dog after Escherichia coli endotoxin had been administered, and Weil et al. (1956) attributed the rise in portal vein pressure to localised venous spasm in the hepatic venous system caused by endotoxin. Chien et al. (1964) found in a study using dogs that portal hypertension caused by endotoxin was accompanied 
by an increase in the wedge hepatic venous pressure and a decrease in the pressure of large hepatic veins, central venous pressure, and hepatic blood flow, and concluded that constriction of hepatic venules or small veins was elicited by endotoxin. On the other hand, Witte et al. (1969) investigated lymph circulation in cirrhotic patients and demonstrated that, when postsinusoidal obstruction predominates, highly permeable liver sinusoids are the major source of increased thoracic duct lymph high in protein but, as presinusoidal block develops, liver lymph is diluted in the thoracic duct by increasing amounts of intestinal lymph low in protein, and protein in thoracic duct lymph fall. Moreover, hepatic lymph has been shown to be related closely to the formation of ascitic fluid especially when hepatic venous outflow block exists (Bolton and Barnard, 1931; Hyatt et al., 1955), and, indeed, it is well known that ascitic fluid resulting from hepatic venous outflow block in man such as in the BuddChiari syndrome (Gibson, 1960; Sherlock, 1968), and in experimental animals (Hyatt and Smith, 1954; Losowsky and Davidson, 1962) is characterised by a high protein content.

These observations suggest that endotoxaemia in patients with cirrhosis and ascites would also exert similar effects and that the ascites produced might contain higher concentrations of protein and that the increased protein concentration and resulting high colloid osmotic pressure of the ascitic fluid would in turn accelerate ascites formation, according to Starling's principle (Starling, 1894; 1896).

The authors are obliged to Professor Kunio Okuda of Chiba University and to Dr Ting D. Poh for their critical review of the manuscript and indispensable assistance in the preparation of the manuscript, and to Mrs Hideko Sato for her technical assistance.

\section{References}

Birkenfeld, L. W., Leibman, J., O'Meara, M. P., and Edelman, I. S. (1958). Total exchangeable sodium, total exchangeable potassium, and total body water in edematous patients with cirrhosis of the liver and congestive heart failure. Journal of Clinical Investigation, 37, 687-698

Bolton, C., and Barnard, W. G. (1931). The pathological occurrences in the liver in experimental venous stagnation. Journal of Pathology and Bacteriology, 34, 701-709.

Braude, A. I., Carey, F. J., and Zalesky, M. (1955). Studies with radioactive endotoxin. II. Correlation of physiologic effects with distribution of radioactivity in rabbits injected with lethal doses of $\mathrm{E}$. coli endotoxin labelled with radioactive sodium chromate. Journal of Clinical Investigation, 34, 858-866.

Chien, S., Sinclair, D. G., Chang, C., Dellenback, R. J., Peric, B., Usami, S., and Gregersen, M. I. (1963). Effect of endotoxin on the transfer of macromolecul ss from plasma to lymph. Physiologist, 6, 157.
Chien, S., Sinclair, D. G., Dellenback, R. J., Chang, C., Peric, B., Usami, S., and Gregersen, M. I. (1964). Effect of endotoxin on capillary permeability to macromolecules. American Journal of Physiology, 207, 518-522.

Clemente, C., Bosch, J., Rodés, J., Arroyo, V., Mas, A., and Maragall, S. (1977). Functional renal failure and haemorrhagic gastritis associated with endotoxaemia in cirrhosis. Gut, 18, 556-560.

Gibson, J. B. (1960). Chiari's disease and the Budd-Chiari syndrome. Journal of Pathology and Bacteriology, 79, 381-401.

Gornall, A. G., Bardawill, C. J., and David, M. M. (1949). Determination of serum proteins by means of the biuret reaction. Journal of Biological Chemistry, 177, 751-766.

Greene, R., Wiznitzer, T., Rutenburg, S., Frank, E., and Fine, J. (1961). Hepatic clearance of endotoxin absorbed from the intestine. Proceedings of the Society for Experimental Biology and Medicine, 108, 261-263.

Hyatt, R. E., and Smith, J. R. (1954). The mechanism of ascites: a physiologic appraisal. American Journal of Medicine, 16, 434-448.

Hyatt, R. E., Lawrence, G. H., and Smith, J. R. (1955). Observations on the origin of ascites from experimental hepatic congestion. Journal of Laboratory and Clinical Medicine, 45, 274-280.

Levin, J., Tomasulo, P. A., and Oser, R. S. (1970). Detection of endotoxin in human blood and demonstration of an inhibitor. Journal of Laboratory and Clinical Medicine, 75, 903-911.

Liehr, H., Grün, M., Brunswig, D., and Sautter, T. (1975). Endotoxaemia in liver cirrhosis: treatment with polymyxin B (Letter). Lancet, 1, 810-811.

Losowsky, M. S., and Davidson, C. S. (1962). The source of ascitic fluid in cirrhosis of the liver. Archives of Internal Medicine, 110, 279-282.

MacLean, L. D., Weil, M. H., Stish, R. J., Spink, W. W., and Visscher, M. B. (1956). Continuously recording quantitative estimation of circulatory changes in the liver and small intestine of the dog following Escherichia coli endotoxin administration (Abstract). Federation Proceedings, 15, 123.

Michaëlsson, M., Nosslin, B., and Sjölin, S. (1965). Plasma bilirubin determination in the newborn infant. Pediatrics, 35, 925-931.

Nolan, J. P., and Ali, M. V. (1972). Effect of cholestyramine on endotoxin toxicity and absorption. American Journal of Digestive Disease, 71, 161-166.

Nolan, J. P., Hare, D. K., McDevitt, J. J., and Ali, M. V. (1977). In vitro studies of intestinal endotoxin absorption. I. Kinetics of absorption in the isolated everted gut sac. Gastroenterology, 72, 434-439.

Ornstein, L. (1964). Disc electrophoresis: I. background and theory. Annals of the New York Academy of Sciences, 121, 321-349.

Prentice, T. C., Siri, W., and Joiner, E. E. (1952). Quantitative studies of ascitic fluid circulation with tritiumlabeled water. American Journal of Medicine, 13, 668-673.

Prytz, H., Holst-Christensen, J., Korner, B., and Liehr, H. (1976). Portal venous and systemic endotoxaemia in patients without liver disease and systemic endotoxaemia in patients with cirrhosis. Scandinavian Journal of Gastroenterology, 11, 857-863.

Ravin, H. A., Rowley, D., Jenkins, C., and Fine, J. (1960). On the absorption of bacterial endotoxin from the gastrointestinal tract of the normal and shocked animal. Journal of Experimental Medicine, 112, 783-792.

Sherlock, S. (1968). Diseases of the Liver and Biliary System, p. 143. Blackwell: Oxford.

Starling, E. H. (1894). The influence of mechanical factors on lymph production. Journal of Physiology (London), 16, 224267. 
Starling, E. H. (1896). On the absorption of fluids from the connective tissue spaces. Journal of Physiology (London), 19, 312-326.

Tarao, K., So, K., Moroi, T., Ikeuchi, T., Suyama, T., Endo, O., and Fukushima, K. (1977). Detection of endotoxin in plasma and ascitic fluid of patients with cirrhosis: its clinical significance. Gastroenterology, 73, 539-542.

Weil, M. H., MacLean, L. D., Visscher, M. B., and Spink, W. W. (1956). Studies on the circulatory changes in the dog produced by endotoxin from gram-negative microorganisms. Journal of Clinical Investigation, 35, 1191-1198.

Wilkinson, S. P., Arroyo, V., Gazzard, B. G., Moodie, H., and Williams, R. (1974). Relation of renal impairment and haemorrhagic diathesis to endotoxaemia in fulminant hepatic failure. Lancet, 1, 521-524.

Witte, M. H., Dumont, A. E., Cole, W. R., Witte, C. L., and Kintner, K. (1969). Lymph circulation in hepatic cirrhosis: effect of portacaval shunt. Annals of Internal Medicine, 70, 303-310.

Yin, E. T ., Galanos, C., Kinsky, S., Bradshaw, R. A., Wessler, S., Lüderitz, U., and Sarmiento, H. E. (1972). Picogram-sensitive assay for endotoxin: gelation of Limulus polyphemus blood cell lysate induced by purified lipopolysaccharides and lipid A from Gram-negative bacteria. Biochimica et Biophysica Acta, 261, 284-289. 